\title{
PENGEMBANGAN LAMPU BAWAH AIR SEBAGAI ALAT BANTU PADA BAGAN TANCAP DI DESA TAMBAK LEKOK KECAMATAN LEKOK PASURUAN
}

\section{DEVELOPMENT OF UNDER WATER LAMP AS A TOOL TO LIFT NET IN TAMBAK LEKOK VILLAGE PASURUAN}

\author{
Fuad*, Sukandar, Alfan Jauhari \\ Dosen Fakultas Perikanan dan Ilmu Kelautan Universitas Brawijaya \\ "Corresponding author e-mail: mrfuad2004@yahoo.com \\ Received: January 19, 2016/Accepted: March 29, 2016
}

\begin{abstract}
Bagan is one type of fishing gear that uses light to collect fish. The lights are expected to stimulate the fish to come and stay around the light and than arrested with net. The use of light for fishing is growing rapidly, almost all fishing gear to use light as a tool for collecting fish. Application of this technology aims to increase fish catch fishermen in District Lekok through the application of technology underwater lamp with LED. Underwater lamp applied to the bagan tancap with a certain intensity and color to find the intensity of light and color that give the best catches. Best catches in the light of 450 lux is capable of delivering the highest total catch of 254 $\mathrm{kg}$, it is supported by the values of illumination of $1.5 \mathrm{lux}$ at a distance of $5 \mathrm{~m}$. Types of fish that were caught on as much as 23 step chart types where the type of Stolephorus spp, Selaroides spp, Leiognathus spp, Loligo sp, Rastrelliger spp is a type of fish that always caught each fishing operation.
\end{abstract}

Keywords: auxilary, development, lamp, Lekok, lift net

\begin{abstract}
ABSTRAK
Bagan merupakan salah satu jenis alat tangkap yang menggunakan lampu sebagai alat bantu pengunpul ikan. Cahaya lampu diharapkan dapat merangsang ikan untuk datang dan berkumpul disekitar sumber cahaya sampai pada suatu catchable area tertentu, lalu penangkapan dilakukan dengan alat jaring maupun pancing. Penggunaan lampu untuk penangkapan ikan saat ini berkembang pesat, hampir semua alat tangkap menggunakan lampu sebagai alat bantu pengumpul ikan. Aplikasi teknologi ini bertujuan untuk meningkatkan hasil tangkapan ikan nelayan bagan tancap di Kecamatan Lekok melalui penerapan teknologi lampu celup bawah air berbasis lampu LED. Lampu celup bawah air diterapkan pada bagan tancap dengan intensitas dan warna tertentu untuk mencari intensitas cahaya dan warna yang memberikan hasil tangkapan yang terbaik. Hasil tangkapan ikan yang terbanyak adalah pada lampu 450 lux yang mampu memberikan total tangkapan terbanyak $254 \mathrm{~kg}$, hal ini didukung dengan nilai nilai illuminasi sebesar 1,5 lux pada jarak $5 \mathrm{~m}$. Jenis ikan yang tertangkap pada bagan tancap sebanyak 23 jenis dimana jenis ikan teri (Stolephorus spp), ikan selar (Selaroides spp), ikan pepetek (Leiognathus spp ), cumi - cumi (Loligo sp), ikan kembung (Rastrelliger spp) merupakan jenis ikan yang selalu tertangkap disetiap operasi penangkapan.
\end{abstract}

Kata kunci: alat bantu, bagan tancap, lampu, Lekok, pengembangan 


\section{PENDAHULUAN}

Perairan laut Kabupaten Pasuruan membentang sepanjang $\pm 48 \mathrm{~km}$ mulai dari Kecamatan Nguling hingga Kecamatan Bangil, dengan luas wilayah laut mencapai sekitar 208,35 km² dengan potensi lestari (MSY) \pm 27.000 ton per tahun. Sarana untuk memanfaatkan potensi perikanan laut, telah dilengkapi pula dengan Pusat Pendaratan Ikan (PPI) yang ditempatkan di Kecamatan Lekok. Kabupaten Pasuruan mempunyai tiga pusat perikanan tangkap yang terletak di Kecamatan Kraton, Lekok dan Nguling dengan 12.059 rumah tangga nelayan dan 2.281 armada penangkapan. Kecamatan Lekok merupakan sertra perikanan tangkap terbesar dengan 5.723 rumah tangga nelayan dan 1.621 armada penangkapan ikan.

Kabupaten Pasuruan mempunyai sembilan jenis alat tangkap dengan jumlah total 2.938 unit dengan rincian, payang 601 unit, tramel net 244 unit, jaring insang 187 unit, jaring klitik 330 unit, pancing 134 unit, bagan tancap 147 unit, pengumpul kerang 1.200 unit dan alat tangkap lainnya 95 unit. Dari semua alat tangkap di atas, hanya bagan tancap yang menggunakan lampu yang berfungsi sebagai alat pengumpul ikan. Bagan tancap merupakan alat tangkap pasif, dimana alat ini berupa bangunan di tengah laut dengan jaring dibawahnya, jaring akan diangkat setelah banyak ikan yang berkumpul ditengah bagan.

Cahaya dapat merangsang ikan untuk datang dan berkumpul disekitar sumber cahaya atau dikenal dengan fototaxis positif. Fungsi cahaya dalam penangkapan ikan ini adalah untuk mengumpulkan ikan sampai pada suatu catchable area tertentu, lalu penangkapan dilakukan dengan alat jaring maupun pancing (Sudirman dan Mallawa, 2004). Penggunaan lampu untuk penangkapan ikan saat ini mengalami perkembangan yang sangat pesat, hampir semua tempat yang terdapat kegiatan perikanan laut, dapat dipastikan terdapat lampu yang digunakan untuk penangkapan ikan. Dalam beberapa tahun terakhir, penelitian batas optimum kekuatan intensitas cahaya telah menjadi salah satu pokok bagian dari penelitian para ahli perikanan laut.

Bagan adalah salah satu jenis alat tangkap yang digunakan nelayan untuk menangkap ikan pelagis kecil. Bagan dalam perkembangannya telah banyak mengalami perubahan baik bentuk maupun ukuran yang dimodofikasi sedemikian rupa sehingga sesuai dengan daerah penangkapannya. Berdasarkan cara pengoperasiannya bagan dikelompokkan dalam jaring angkat (lift net), namun karena menggunakan cahaya lampu untuk mengumpulkan ikan maka disebut juga light fishing (Subani dan Barus, 1989). Berdasarkan mobilitasnya, alat tangkap bagan dibagi dua yaitu bagan tancap dan bagan apung. Bagan tancap sifatnya menetap sedangkan bagan apung dapat berpindah dari satu daerah penangkaapan ke daerah penangkapan lainnya.

Kelompok nelayan bagan tancap di Kecamatan Lekok sebagian besar masih menggunakan lampu petromak sebagai alat bantu pengumpul ikan. Lampu petromak cenderung kurang efisien dan kurang efektif untuk mengumpulkan ikan.

Maksud dari program pengabdian masyarakat ini adalah untuk meningkatkan hasil tangkapan ikan nelayan bagan tancap di Kecamatan Lekok melalui penerapan teknologi lampu celup bawah air berbasis lampu LED. Sedangkan tujuan khusus dari program pengabdian ini adalah:

1. Mengetahui hasil tangkapan ikan pada bagan tancap yang beroperasi di perairan Lekok Pasuruan.

2. Mengetahui hasil tangkapan ikan paling banyak pada bagan tancap dengan alat bantu lampu bawah air.

3. Meningkatkan efektifitas operasi penangkapan ikan pada bagan tancap di Kecamatan Lekok. 
ISSN: 1907-9931 (print), 2476-9991 (online)

Lampu pengumpul ikan yang digunakan oleh kelompok nelayan bagan tancap di Kecamatan Lekok masih menggunakan lampu petromak dengan bahan bakar minyak tanah. Cahaya lampu petromak cenderung lebih redup dan tidak mampu menembus air laut sampai kedalaman 5 meter. Selain itu, hampir setiap hari terjadi kerusakan pada lampu petromak terutama pada kaos lampu sebagai sumber cahaya.

Nelayan bagan tancap di Kecamatan Lekok juga mengalami permasalahan tentang aplikasi teknologi lampu yang kurang efisien. Penggunaan lampu yang diletakkan di atas air, $70 \%$ cahaya yang dipencarkan dipantulkan lagi keatas oleh permukaan air. Berdasarkan hasil penelitian yang dilakukan oleh BBPPI Semarang (2007) mengatakan bahwa penurunan nilai luminasi cahaya mencapai $\pm 99 \%$ pada lampu galaxy 400 watt setelah berkas cahaya menembus permukaan air laut.

\section{MATERI DAN METODE}

Program pengabdian masyarakat dilaksanakan di Desa Tambak Lekok Kecamatan Lekok, Kabupaten Pasuruan. Pelaksanaan Program dilaksanakan dalam beberapa tahap yaitu tahap pertama perancangan dan pembuatan alat lampu bawah air, tahap kedua melaksanakan diskusi kelompok terbatas, tahap ketiga uji coba dan pelaksanaan program, tahap keempat evaluasi program. Program dilaksanakan selama 3 bulan yaitu dari bulan September - Nopember 2015.

Bahan dan alat yang digunakan dalam pelaksanaan pengabdian kepada masyarakat terdiri dari peralatan yang dibeli dalam bentuk jadi seperti generator dan peralatan yang perlu dirakit/dibuat sendiri seperti stabiliser arus, housing lampu dan dimmer.

Aplikasi lampu bawah air dilaksanakan di perairan Lekok dimana setiap setting dilakukan selama 3 jam, di sela - sela waktu menunggu 3 jam dilakukan pemantauan terhadap jumlah ikan yang datang menghampiri lampu bawah air. Pemantauan jumlah ikan yang datang dan berada disekitar cahaya lampu bawah air diamati menggunakan echo-sounder type GPS Map 178C Sounder. Selain itu dilakukan pengukuran intensitas cahaya lampu menggunakan luxmeter Gossen Panlux Electronic 2 made in Germany dengan 9 skala yakni skala 20 lux, 60 lux, 200 lux, 600 lux, 2000 lux, 6000 lux, 20000 lux, 60000 lux, 200000 lux. Untuk mendapatkan angka yang sangat rinci perlu diukur illuminasi dari lampu - lampu yang digunakan.

Proses pengoperasian lampu bawah air pada bagan tancap dimulai pukul 18.30 - 05.00, sehingga dalam 1 trip hanya ada 3 kali setting yang dikelompokkan dalam 3 kategori yaitu setting 1 (sebelum tengah malam pukul 18.30 - 21.30), setting 2 (saat tengah malam pukul $22.00-$ 01.30 ), dan setting 3 (setelah tengah malam pukul 02.00 - 05.00). Proses pengamatan dilakukan dengan pengamatan langsung dan menggunakan camera underwater untuk melihat tingkah laku ikan pada kedalaman di atas $3 \mathrm{~m}$.

\section{HASIL DAN PEMBAHASAN}

Selama pelaksanaan program pengabdian masyarakat dilakukan uji coba lampu bawah air dan pengukuran kualitas air untuk mengidentifikasi pengaruh lingkungan terhadap keberhasilan operasi penangkapan ikan. Berdasarkan hasil pengukuran kualitas air diperoleh informasi bahwa perairan disekitar bagan tancap memiliki kisaran suhu $26.5^{\circ} \mathrm{C}-31^{\circ} \mathrm{C}$ dengan salinitas kisaran $18 \%$ - $33 \%$ dan tingkat kecerahan berkisar 1,86 - 2,075 m. Kondisi cuaca sangat berpengaruh terhadap keberhasilan operasi penangkapan ikan, dimana arus, angin dan perbedaan suhu perairan akan mendorong terjadinya upwelling. Jika upwelling terjadi maka pengoperasian alat dihentikan sementara sambil menunggu kondisi perairan yang kondusif. Kondisi cuaca sangat berpengaruh terhadap kondisi perairan dan kondisi perairan juga berpengaruh pada distribusi ikan. 
ISSN: 1907-9931 (print), 2476-9991 (online)

Jenis ikan yang tertangkap selama pelaksanaan uji coba lampu bawah air pada program pengabdian kepada masyarakat dapat digolongkan menjadi tiga yaitu ikan pelagis, demersal dan reef associated. Total hasil tangkapan selama percobaan lampu bawah air sebesar $591 \mathrm{~kg}$, sedangkan jenis ikan yang dominan tertangkap berturut - turut adalah jenis ikan teri (Stolephorus spp), ikan selar (Selaroides spp), ikan pepetek (Leiognathus spp ), cumi - cumi (Loligo sp), ikan kembung (Rastrelliger spp). Kelompok ikan lainnya yang tertangkap pada bagan tancap adalah udang mantis (Squilla spp), udang (Penasesus sp), rajungan (Portunus sp), gurita (Octopus), sotong (Sepia sp), ubur - ubur (Aurelia sp), ikan beloso (Saurida sp), ikan kakap (Lutjanus spp), ikan Lemuru (Sardinella spp), ikan julung - julung (Hemiramphus sp), ikan sembilang (Plotosus $s p$ ), ikan belanak (Mugil sp), ikan alu - alu (Sphyraena spp), ikan bulu ayam (Thryssa sp), ikan sebelah (Psettodidae sp), ikan putihan (Caranx sp), ikan keeper (Scatophagus $s p$ ) dan ikan layur (Trichiurus $s p$ ). Kelompok ikan ini mempunyai hasil tangkapan yang sangat kecil per jenisnya.

Selama pelaksanaan uji coba lampu bawah air di bagan tancap terdapat 23 jenis ikan yang tertangkap. Pengamatan ini juga memberikan informasi bahwa jenis ikan teri (Stolephorus spp), ikan selar (Selaroides spp), ikan pepetek (Leiognathus spp), cumi - cumi (Loligo sp) dan ikan kembung (Rastrelliger spp) merupakan jenis ikan yang selalu tertangkap di bagan tancap walaupun terdapat perbedaan perlakuan intensitas selama penggunaan lampu bawah air. Intensitas cahaya lampu bawah air yang diuji coba pada pengabdian kepada masyarakat terdiri dari empat perlakuan yaitu intensitas 30 lux, intensitas 230 lux, intensitas 250 lux dan intensitas 450 lux. Hasil tangkapan lampu bawah air secara keseluruhan lebih banyak dibandingkan dengan hasil tangkapan dengan lampu petromak. Lampu bawah air mampu mengumpulkan ikan cukup banyak dengan jenis ikan yang paling dominan adalah ikan selar (Selaroides spp). Hal ini sejalan dengan hasil penelitian Sudirman et al. (2003) yang melakukan penelitian dengan mengkomparasikan adaptasi retina ikan tembang (Sardinella fimbriata) dan ikan selar (Selar crumenopthalmus). Hasil pengamatan menunjukkan bahwa ikan tembang terakumulasi pada zona iluminasi 10 - 100 lux, sedangkan ikan selar antara 100 lux sampai 200 lux. Jadi ikan selar sangat menyukai intensitas cahaya yang cukup tinggi. Perlakuan empat dengan intensitas cahaya 450 lux memperoleh hasil tangkapan dominan yang berbeda. Perlakuan empat memperoleh hasil tangkapan ikan teri (Stolephorus spp) yang paling banyak. Ikan teri memiliki sifat bergerombol dalam jumlah yang banyak dan memiliki sifat fototaksis positif terhadap sumber cahaya. Sudirman dan Natsir (2011) menyatakan bahwa ikan teri diduga mempunyai sifat fototaksis positif yang sangat tinggi, sedangkan spesies lainnya disamping sifat fototaksis juga karena dorongan mencari makan. Faktor lainnya adalah perbedaan jumlah ikan dalam gerombolannya. Sudirman dan Natsir (2011) menunjukkan bahwa pada bagan tancap distribusi ikan lebih terkonsentrasi pada kedalaman $2-4 \mathrm{~m}$. Jenis - jenis ikan yang berada pada kedalaman tersebut antara lain adalah peperek dan ikan teri. Jenis ikan yang senang dipermukaan air adalah kepiting dan rajungan

Berdasarkan hasil pengamatan menunjukkan bahwa lampu 30 lux memberikan total tangkapan $91.5 \mathrm{~kg}$ dengan rata - rata hasil tangkapan $15.25 \mathrm{~kg}$, lampu 230 lux memberikan total hasil tangkapan ikan $146 \mathrm{~kg}$ dengan rata - rata hasil tangkapan $24.33 \mathrm{~kg}$, sedangkan untuk lampu 250 lux memberikan total tangkapan ikan $99.5 \mathrm{~kg}$ dengan rata - rata hasil tangkapan $16.58 \mathrm{~kg}$, dan lampu 450 lux memberikan total tangkapan ikan $254 \mathrm{~kg}$ dengan rata - rata hasil tangkapan 42.33 $\mathrm{kg}$. Hasil tangkapan ikan yang terbanyak adalah pada lampu 450 lux yang mampu memberikan total tangkapan terbanyak $254 \mathrm{~kg}$ hal ini didukung dengan nilai illuminasi cahaya sebesar 1.5 lux pada jarak $5 \mathrm{~m}$. Jika dibandingkan dengan perlakuan lainnya seperti 230 lux, 250 lux dan 30 lux, nilai iluminasi cahaya pada tiap-tiap perlakukan sebesar 0.5 lux, 1 lux, dan 0 lux.

Pengamatan tingkah laku ikan juga menggunakan alat akustik untuk melihat tingkah laku ikan dibawah air, namun penerapan alat akustik ini masih sederhana dan belum mampu membedakan jenis ikan yang datang pertama dan bagaimana pola gerak ikan menuju bagan. Ada interaksi yang terjadi pada tiap jenis ikan yang berada disekitar bagan. Berdasarkan hasil penelitian Sudirman et al. (2011), menunjukkan bahwa pada ikan selar, laying dan kembung selalu 
ISSN: 1907-9931 (print), 2476-9991 (online)

memburu dan memangsa jenis ikan crustacean, moluska dan plankton. Ikan teri kebanyakan memakan jenis fitoplankton, zooplankton dan larva.

\section{KESIMPULAN DAN SARAN}

Berdasarkan hasil pelaksanaan uji coba lampu bawah air pada program pengabdian kepada masyarakat dapat disimpulkan bahwa hasil tangkapan ikan yang paling dominan pada lampu bawah air dengan intensitas 30 lux, 230 lux dan 250 lux adalah ikan selar sedangkan lampu dengan intensitas 450 lux adalah ikan teri. Hasil tangkapan ikan paling banyak adalah menggunakan lampu bawah air dengan intensitas 450 lux yaitu memperoleh hasil tangkapan sebesar $254 \mathrm{~kg}$ dengan rata-rata hasil tangkapan 42,33 kg/trip. Penggunaan lampu bawah air pada bagan tancap menghasilkan hasil tangkapan ikan yang lebih banyak dibandingkan dengan menggunakan lampu petromak.

Penggunaan teknologi lampu bawah air cukup rumit bagi nelayan tradisional, untuk itu perlu pendampingan yang inten agar berjalan dan lebih berhasil.

\section{UCAPAN TERIMA KASIH}

Ucapan terima kasih kami sampaikan kepada Direktorat Jenderal Pendidikan Tinggi (DIKTI) yang telah membiayai program pengabdian kepada masyarakat ini dan Badan Kerjasama, Penelitian dan Pengabdian Masyarakat FPIK UB, serta semua stakeholder yang telah membantu pelaksanaan program pengabdian masyarakat ini.

\section{DAFTAR PUSTAKA}

BBPPI Semarang (2007). Klasifikasi alat penangkapan ikan. Balai Besar Pengembangan Penangkapan Ikan. Semarang

Subani, W., \& Barus, H. R. (1989). Alat penangkapan ikan dan udang di Indonesia. Nomor 50 tahun 1988/1999. Edisi khusus. Jurnal Penelitian Perikanan Laut. Jakarta: Balai Penelitian Perikanan Laut. Departemen Pertanian. Jakarta. $248 \mathrm{Hal}$

Sudirman \& Mallawa, A. (2004). Teknik penangkapan ikan. Rineka Cipta, Jakarta

Sudirman, Hade, A. R., \& Sapruddin (2011). Perbaikan tingkat keramahan lingkungan alat tangkap bagan tancap melalui perbaikan selektivitas mata jaring. Bulletin Penelitian LP2M Universitas Hasanuddin, 2(1), 47- 67.

Sudirman, Baskoro, M. S., Purbayanto, A., Monintja, D. R., Jufri, M., \& Arimoto, T. (2003). Adaptasi retina mata ikan layang (Decapterus ruselli) terhadap cahaya dalam proses penangkapan pada bagan rambo di Selat Makassar. Jurnal IImu-IImu Perairan dan Perikanan Indonesia, 10(2), 85-92.

Sudirman \& Natsir (2011). Perikanan bagan dan aspek pengelolaannya. UMM Press, Malang 